\title{
The Integration of Prophetic Values in Developing the Teachers' Personality Competency Assessment Instrument
}

\author{
Atim Rinawati \\ Graduate School, \\ Universitas Negeri Yogyakarta \\ Yogyakarta, Indonesia \\ atim.rinawati2016@student.uny.ac
}

id

\author{
Kumaidi \\ Graduate School, \\ Muhammadiyah University of \\ Surakarta \\ Surakarta, Indonesia \\ kum231@ums.ac.id
}

\author{
Harun \\ Graduate School \\ Universitas Negeri Yogyakarta \\ Yogyakarta, Indonesia \\ harun@uny.ac.
}

\begin{abstract}
This study aimed to identify the prophetic values of Islam to find indicators that can be used as a reference in the development of the assessment instrument of teacher's personality competence. This study was written using the method of inductive content analysis. From the results of this study it was found 9 (nine) indicators of prophetic-based personality of a teacher, they were 1). Having transcendent personality, 2). Having a liberating spirit, 3). Humanist, 4). Mastering the materials to be taught, 5). Having good teaching methods, 6). Able to be an ideal model for students, 7). Able to conduct evaluation with amar ma'ruf nahi munkar, 8). Having a high commitment in carrying out the task, 9). Having good communication skills. These nine indicators can be used as references in the development of the assessment instrument of teacher's personality competence through the principles of composing the assessment instrument.
\end{abstract}

Keywords - integration, prophetic values, development, assessment instrument, personality, teacher

\section{INTRODUCTION}

Teacher is the most influential figure on the quality of education. The presence of teachers in front of the class is an absolute condition that must exist so that the learning process runs properly. They are a very dominant element in learning activities and cannot be replaced by any sophisticated technology. The development of technology in the field of education which manifested by the variety of learning media and learning aids is not necessarily able to replace the presence of teachers in the classroom. Students need human elements that directly derived from the presence of teachers in the classroom, such as attitudes, values, feelings, characters and personality that cannot be maximally obtained from technology.

If we look at the national education objectives as stated in Article 3 of Law No. 20 of 2003 on National education system, it states: The National education function to develop the ability and form the characters and civilization of a dignified nation in order to educate the nation's life. It aims for the development of learners' potential to become men with faith, believe, and devoted themselves to God Almighty, having noble characters, healthy, knowledgeable, capable, creative, independent, and being a democratic and responsible citizen. The teachers' personality aspect must be a concern for education providers. Teachers' personality has a very big influence on the success of education especially in learning activities.

In the context of personality, Mulyasa states that teachers' personality really determines the students' personality forming [1]. Teachers who in everyday life are well behaved, discipline, friendly, courteous in appearance and the way of speaking and able to provide solutions to the problems faced by students are said to have a good personality or have a noble character. The teachers' personality is often used as a high parameter or low teachers' authority in the eyes of learners and society [2]. The authoritative teachers have an inner radiance that can attract the attention of their students to receive, enjoy, honor, obey and emulate is their attitudes and good deeds both within and outside the learning activities. The authority possessed by a teacher is the result of a long process until a teacher has maturity both physically and spiritually, has fixed ideals and perspectives of life, and is formally demonstrated by the certificate as a proof that the teacher has fulfilled the competences to carry out the profession responsibilities as a teacher. Santrock mentions that a teacher must have professional knowledge and skill as a unified whole which is a pre-requirement for professional teachers [3]. The most important requirement of educators is the main personality that must be possessed by the teacher [4]. From the personality that is possessed, an educator can be evaluated whether he is a good educator or not. A teacher who has a good personality is very likely to have good pedagogical, social, and professional competence as well. Personality is a competence that determines the accomplishment of the other competences. The whole personality includes behavior and verbal expression. The students and the surrounding community can see teachers who have a good personality from his behavior that can be used as a model in which the actions that do not violate the norms of religious and society. Teachers who have a good personality can also be seen from his speech that 
is polite and meaningful and has the persuasive power to invite students to speak with polite language.

The great influence of teacher's personality competence on the process of education and the little attention from the government to do the assessment as it has done for pedagogical and professional competences in Teacher Competency Test (UKG) is a challenge and opportunity to develop teacher's competence assessment instrument. The question then arises as to how the constituents of the instrument, while the concept of personality set by the government in Law No. 14 of 2005 has not yet been summarized into clear dimensions and indicators. It is necessary to use a scientific approach to interpret the concepts better so that it becomes a measurable indicator. To address the problem, the prophetic paradigm can be used as an approach to examine personality competencies more concretely and profoundly, as a reflection of a teacher's personality.

This study aims to identify the prophetic values of Islam especially Prophet Muhammad SAW related to his figure as a teacher. The prophetic values are integrated in composing the assessment instrument of teacher's personality competence through instrument indicators. This study is the first step in developing the assessment instrument of teacher's personality competence.

\section{LITERATURE REVIEW}

The teacher's personality competence and prophetic approach are studies that have been done before. The following are some of studies that discussed the same topic.

- A research related to the teacher's personality with the title "Impact of Teacher Personality Styles on Academic Excellence of Secondary Students" which was written by Patricia Garcia and Ed. D. Marshall. This study aimed to measure and compared the personality characteristics of prospective teachers in educational institutions of prospective teachers in Punjab, Pakistan. The measurements are based on the Big Five Inventory (BFI) developed by Oliver P. John with slight modifications, Extraversion, Agreeableness, Conscientiousness, Neuroticism and Openness [19]. The study involved a sample of 100 prospective teachers consisting of 60 women and 40 men. The collected data were analyzed using descriptive and inferential statistical techniques such as mean and t-test. The result of the study was the openness personality (openness) of the teacher was more dominant than the four other personalities. Another finding was that female prospective teachers had superior scores on five personalities compared to the male teacher candidates. Garcia's study is similar with this one where both assess the teacher's personality. The difference between the two is the approach used in the study; Garcia's study used Big
Five Inventory (BFI) as the approach while this study used prophetic of Islam [5].

- A research related to the teacher's personality with the title "A Teacher Personality Competence Contribution to A Student Study Motivation and Discipline to Fiqh Lesson" which was conducted by Ade Een Khaeruniah. This study aimed to determine the extent to which the contribution of teacher personality to the motivation and discipline of students, especially on Fiqh Subject. The researcher chose quantitative methods of experimental type using correlation coefficient. The respondents were students of MTs Negeri Cikanjung, Bandung Regency, West Java with a total student of 72 that were determined by stratified random sampling. The result of this research was that the competence of a teacher's personality had contributed to student's learning motivation. The influence of the teacher's personality competence to motivate students was $46,1 \%$. The teacher's personality competence influence students' discipline by $51,7 \%$ and there was a significant correlation between student motivation and discipline by 0,386 . The study conducted by Een became a very strong basis for the importance of developing the teacher's personality competency instrument, emphasizing on how significant teacher's personality influence on the quality of students, especially the students' discipline and motivation [6].

- A study, entitled "Effects of Perceived Teacher Personality on Student Class Evaluations" which was written by Yoshitaka Tanabe \& Setsuko Mori, aimed to determine the effect of students' perceptions of teachers' personalities on their judgments. In this case, a comparison between two English teachers who one of them was native Japanese and the other was a native speaker from England. Tanabe and Mori conducted this study at a private university in Japan with respondents of 160 students in a row from Grade 1 to 2 which were taught by those two English teachers, the English teacher from the UK and the English teacher from Japan. The results of this study stated that students had the perception that the native speaker instructor had an aggressive personality, dominate, authoritarian and trigger students to worry. Meanwhile, the instructor from Japan had a friendly, ambitious, intellectual, intelligent and gentle personality. Cultural and linguistic similarities can affect perceptions. The result of Yoshitaka's research shows that the teacher's personality gives a huge influence on the acceptance of the students, so it is necessary to involve the students in the teacher's personality assessment activities. Students should be a party to assess the personality of teachers with their perceptions [7].

- A research entitled "Personality Measurement and Assessment in Large Panel Surveys" which was written by Brent Roberts, Joshua J. Jackson, Angela L. Duckworth Katherine Von Culin. This article discussed personality tests carried out in large panels 
such as Health and Retirement Study (HRS). The conclusion of this article is that there should be an early attempt at incorporating personality parameters into HRS. Ideally, new test construction should be tested first. Another recommendation is an alternative to use self-report to be more effective [8].

- A research relates to a prophetic approach entitled "Methodology of Prophetic Da'wah and Relevance to Contemporary Global Society" which was written by Fr. Shehu. This study aimed to examine methods propagation of prophets and extracted them to be applied as a contemporary Da'wah method. The method used in this research was descriptive. The research of Fatmir Shehu has similarities with this where both studies use the life history of Prophet Muhammad to be used as an example of life in the present. The difference between the two lies in the specification of the study. In the Fatmir Shenu study, it examined the propagation method of prophets in general while this research particularly studies the task of today's teachers [9].

- A research entitled "The Prophetism Dimension of Social Sciences Perspective Development by Kuntowijoyo which was written by Syamsul Arifin". There are three prophetic pillars according to Kuntowijoyo, namely liberation, humanization, and transcendence. These three pillars construct the basis for the indicators in composing indicators of the assessment instrument of teacher's personality competence [10].

\section{ABOUT PROPHETIC KNOWLEDGE}

\section{A. Characteristic of Prophetic Knowledge}

Further, according to Geraudy, prophetic philosophy moves the human potential in a positive direction in the nuances of divinity and prophet hood. This philosophy also tipping the philosophy of love that ultimately produces a philosophy of motion. The philosophy of motion is the success key of the Prophet's mission in improving the quality of mankind. It means, prophetic philosophy teaches the need for a real action in carrying out tasks in life, not merely a concept or theory. According to Geraudy, prophetic philosophy is not only limited to communication between man and nature, but a further communication which capable in creating a harmonious relationship with God [11]. The prophetic philosophy leads men to the nuances of the divinity and prophet hood that will encourage people in a positive direction. The Islamic philosophy accepts the sensory things are real but has the belief that the sensory or empirical things are not the only reality. This is different from western philosophy.

Prophetic knowledge has different characteristics with other disciplines. In contrast to empirical knowledge which regards the source of knowledge only from empirical experiences, prophetic knowledge must recognize the existence of an empirical and non- empirical source of knowledge [12]. The Prophets had the ability to see and feel the unseen world that has no empirical traits but must be acknowledged by prophetic knowledge. Ahimsa Putra describes some sources of prophetic knowledge that is Allah the Almighty Creator, the revelation of Allah, the supernatural, The Messenger and prophets, the man, the Hadith, the history of the prophets and The Messenger, the research of the scholars, the customs, and the physical realm. These knowledge sources are more likely to be non-empirical.

There is a very basic reason why the prophets served as the ultimate example of life on earth. Prophet is a figure who has a superior character and ideal both physical and psychic and capable of establishing effective communication with God and angels [13]. Prophets are human figures who have extraordinary features that distinguish the human in general. A prophet has extraordinary self-preparation because of the magnitude task he has. Not only the ideal physical potential, a prophet also has a noble descendant as well as a formidable physical condition to establish the revelation of Allah. With such extraordinary piety, the prophet has the ability and power to convey the revelation of Allah to mankind with various trials and tough tests.

One other privilege thing possessed by a prophet is the ability to predict the future of both lives in the world and in hereafter. This predictive ability is followed by the high spirit of the prophets to bring people to a good quality of life in the world and in hereafter. The high spirit of the prophets can be seen from the persistence in passing the tests during propagation. It can be exemplified by the persistence of the Prophet Muhammad in propagating Islam amongst insults and ridicule of the polytheists. Allah says, "And they say, O you upon whom the message has been sent down, indeed you are mad" (Q.S. al-Hijr: 6 ). The polytheist that time even called the prophet and his followers as crazy. This outrage was intended to destroy the ranks and spirit of the Muslims in upholding the teachings of Islam. At that time, Prophet Muhammad remained with a strong determination unaffected by the insults of those who block the propagation of Islam, and able to maintain the spirit stability of the Muslims to keep fighting in the way of Allah.

Allah Ta'ala says (which means), "And they wonder that there has come to them a warner from among themselves. And the disbelievers say, "This is a magician and a liar." (Q.S. Sad: 4). From this verse, Prophet Muhammad not only got insults and reproaches, but also got a very cruel slander from the polytheists. However, the prophet is a special person who gained the extraordinary grace of God in performing his propagation duties. This kind of determination should be exemplified by mankind 
today, especially the teachers in carrying out their duties to educate the students.

The educational studies conducted through a prophetic approach means that education is a major agenda of a nation that has a predictive power in the future. Education based on the concepts of prophet hood can be a very strategic asset to the society, nation, and state life that is full of values of goodness.

The prophetic potency of prophecy can be internalized within the individual after someone performs an adequate educational procedure with mental, spiritual, physical, and social work to find normative and factual truth. It takes a formidable human figure to create an education with prophetic values. All elements involved in the management of education should have a high commitment to realize the values of prophet hood in every level of education. Teachers as the expectancy in the educational process have a very vital role towards the achievement of educational goals. Teachers, who oversee their duties, enormously contribute to generate the quality of education as expected by the government and society in general.

The tremendous potential given by God in a prophet can be proven by the possession of the noble qualities of a prophet. This noble character is the one that distinguishes between prophets as human beings and other human beings in general. First, the prophet has the nature of the consistence center (always based on conscience and truth). The great ability to communicate with The Creator built an exceptional spiritual level in which all behavior and words of the prophet is a communication manifestation with The Creator and filled with the values of goodness and truth. Second, prophets have highly committed qualities (professionalism and commitment). Prophetic task is a heavy task and directly related to the owner of life that is Allah SWT or the angel as an intermediary. The Prophets are the chosen human being who have the professionalism and commitment tested in carrying out the task of the creator to govern human life on earth. Third, the prophets have the nature communication skills (skills in communicating). The Prophets as perfect human being possessed a high-level communication ability especially in communicating the messages of heaven in the form of revelations revealed by God which are then written in the books of God. The Prophets had a very heavy task of delivering messages from The Creator to people as a guide to live in the world and hereafter. Surely, a prophet had good language skills in front of people at that time so that his teachings could be followed. Fourth, the prophets had the ability to solve problems (problem solver). God sent a prophet to be a solution-giver during a society that was troubled by problems. In solving the problems during society, the prophet was not merely as a reliever or neutralizer, but he could provide the best solution to solve the problem wisely [13].

The practice of education had been practiced by the prophets where they were the teachers and their people were the students, as what Prophet Muhammad SAW did at that time. Educational practices that were implemented more than 16 centuries ago, are still relevant to be practiced by the teachers in the $21 \mathrm{st}$ century. Here are the educational practices conducted by Prophet Muhammad SAW:

- The prophet must master the materials collected in the Qur'an and Hadith that were compatible to the needs of students/people throughout the ages.

- The prophet mastered an effective method to convey the message in order to touch the souls of the people as students.

- The prophet controled/evaluated the quality with amar ma'ruf (command to do positive things), nahi mukar (prohibition to do negative things), as well as recommendations related to the truths $(h a q)$ and patience.

- The prophet posed himself as the ideal model for people in thinking and arranging the life of the world and hereafter.

\section{B. Pillars of Prophetic Knowledge}

Kuntowijoyo formulates three dimensions of the prophetic paradigm: transcendence (bringing people to the faith in God), liberation (liberation from oppression), and humanization (humanizing human beings). The following is a more detailed explanation of the three dimensions of the prophetic paradigm. The purpose of transcendence is to add a transcendental dimension in culture, ridding itself from the current flow of hedonism, materialism, and decadent culture. The transcendence dimension is meant for people to feel the world again as God's grace, to live in a free atmosphere from space and time, when we encounter God's greatness. The Pillar of Humanization deals with how Muhammad became a very humanist person. Muhammad was a person who really appreciated others, even to people who were openly hostile to him. Liberation in the view of Kuntowijoyo is the knowledge language of nahi munkar. If in the language of religion nahi munkar means to prevent from all crimes that damage, eradicate gambling, loan sharks, corruption, and others, then in the language of science, nahi munkar means liberation from ignorance, poverty or oppression. etymologically, liberation is derived from the Latin word liberare which means liberate. In terms, it can be interpreted with liberation, all with connotations that have social significance.

\section{TEACHER PERSONALITY ASSESSMENT}

The professional teachers as required in Law number 20 of 2003 on National Education System and strengthened by Law no. 14 OF 2005 About Teachers and Lecturers, there are various parameters until the 
teacher is said to be professional. The fulfilment of teacher's personality competence is one of the regulation requirements among other requirements, such as pedagogical competence, social competence, professional competence, physical and spiritual health, fulfilling the academic qualifications, and having certificates as educators. As mandated by the Law, teachers should have a steady, stable, mature, wise, authoritative personality, become role models for the students, and have a noble character. The fulfilment of personality competence becomes very important especially for a teacher who.

Personality assessment, especially in the world of work has a very important role to improve the quality of human resources. Personality assessment is one way to find out how far the human resources are involved in the institution. Policies related to human resources, such as recruitment, promotion, and transfer of require the results of a personality test as a consideration. Cohen and Swerdik categorize personality assessments produced through informants into 2 (two), namely selfreport and peer assessment. Self-assessment can be done directly or indirectly by: (1) asking respondents to answer questions through interviews, (2) assessment in the written test either by marking on paper or by using computer [14]. Furthermore, Cohen and Swerdik say that peer assessments can be done by requesting information about individuals to other relevant people. For example, to assess the personality of a teacher can be done through peer research such as the principal, observers, parents, students and even students [14].

Personality of a person will affect the performance. This is what triggers a lot of personality development efforts. A teacher who has a good personality is very possible to have a good performance and loyalty profession as well. A teacher who has a good personality will be aware of his duties and obligations and has a high spirit to continue to improve the quality of himself in his position as an educator [15].

Competence is several characteristics that underlies a person and shows (indicate) ways of acting, thinking, and/or generalizing things properly in the long run [16]. In relation to performance, Spencer says that competence is a basic characteristic that a person has in adjusting to the criteria which are required for effective and superior performance in accordance with the demands of task and environment [16]. It means that competence in performance is related to one's efforts to meet the required performance standards. If the ability of a person in a field is in accordance with the required standards, then he is declared to have fulfilled the competency/ competence. Conversely, if a person has not been able to meet the minimum standards of the required ability in a field of work, then he has yet to meet the competency/competence.
Competence is several characteristics that underlies a person and shows (indicate) ways of acting, thinking, and/or generalizing things properly in the long run [16]. In relation to performance, Spencer says that competence is a basic characteristic that a person has in adjusting to the criteria which are required for effective and superior performance in accordance with the demands of task and environment [16]. It means that competence in performance is related to one's efforts to meet the required performance standards.

Personality according to Atkinson is all different patterns of thoughts, emotions, and behavior and is a characteristic that determines the personal style of the individual and influences his interaction with the environment [17]. Personality is the original patterns of behavior that settle within the individual. In everyday life, personal style is a manifestation by interacting with others, which is based on the pattern of thoughts and emotions. Having a mature personality is a requirement that must be fulfilled by someone in the association and in various professions, especially a teacher. Personality in Islam has the same meaning with the word akhlak, Sulukkiyah (behavior), khuluqiyah (akhlak) infi'aliyah (emotion), jasadiyyah (physical), qadarah (competence), muyul (interest). While khuliqiyyah is habit or will.

According to a research conducted by Hebert and Breadley, personality of a person will affect the performance [18]. This is what triggers the number of efforts in developing the personality. Human personality can change along with the development, knowledge, and skills of a person [16]. Factors affecting the human personality are heredity, the interaction between heredity with the community, and the interaction between descendant and environment.

Personality formation is done through education, training, coaching, role modeling, and habituation. As explained in the Qur'an, Allah takes man out of his mother's womb and in the state of knowing nothing, and God gives the human hearing, sight, heart or mind to be used to fulfill everything that exists in this world Surah An-Nahl.

\section{THE INDICATORS OF PROPHETIC-BASED PERSONALITY OF TEACHER}

The Prophet is the ideal human figure both physically and psychologically who is the worthiest of being an example to mankind on earth in all life. The Prophet is the figure of God's chosen man who had been tested and proved to have extraordinary courage in carrying out his propagation among humanity filled with challenges. Based on the above description, there are prophetic indicators of Islam that can be used as a basis in the development of the assessment instrument of teacher's personality competence. Here are 9 (nine) indicators. 
TABLE I. THE INDICATORS OF PROPHETIC-BASED PERSONALITY OF TECHER

\begin{tabular}{|c|c|}
\hline Indicators & Explanation \\
\hline $\begin{array}{l}\text { Having } \quad \text { transcendent } \\
\text { personality }\end{array}$ & $\begin{array}{l}\text { Teachers in carrying out their } \\
\text { duties always base on the values of } \\
\text { God, both in faith and deeds. }\end{array}$ \\
\hline Having a liberating spirit & $\begin{array}{l}\text { Teachers possess the passion for } \\
\text { freeing students from ignorance by } \\
\text { guiding them sincerely. }\end{array}$ \\
\hline Humanist & $\begin{array}{l}\text { Teachers have the nature of } \\
\text { humanizing/respecting their } \\
\text { students, away from the nature of } \\
\text { seniority that keeps students away } \\
\text { from teachers. }\end{array}$ \\
\hline Mastering the materials & $\begin{array}{l}\text { Teachers should master the subject } \\
\text { matter to be taught. }\end{array}$ \\
\hline $\begin{array}{l}\text { Having good teaching } \\
\text { methods }\end{array}$ & $\begin{array}{l}\text { Teachers should have good teaching } \\
\text { methods, so that all messages/subject } \\
\text { matter can be accepted by students as } \\
\text { expected. }\end{array}$ \\
\hline $\begin{array}{l}\text { Able to be an ideal model } \\
\text { for students }\end{array}$ & $\begin{array}{l}\text { Teachers should be able to be good } \\
\text { examples for their students in } \\
\text { thought patterns, words, and deeds. }\end{array}$ \\
\hline $\begin{array}{l}\text { Able to conduct evaluation } \\
\text { with amar ma'ruf nahi } \\
\text { munkar }\end{array}$ & $\begin{array}{l}\text { Teachers are able to give evaluation; } \\
\text { in this case, the assessment is either } \\
\text { formally according to the rules of the } \\
\text { institution or through nahi munkar. }\end{array}$ \\
\hline $\begin{array}{l}\text { Having a r high } \\
\text { commitment in carrying } \\
\text { out the task }\end{array}$ & $\begin{array}{l}\text { Teachers should have a commitment } \\
\text { as weapon in carrying out the task, } \\
\text { which is evidenced by the toughness } \\
\text { in facing every problem. }\end{array}$ \\
\hline $\begin{array}{l}\text { Having good } \\
\text { communication skills }\end{array}$ & $\begin{array}{l}\text { Teachers should have a good way to } \\
\text { communicate which is evidenced by } \\
\text { the ability using appropriate } \\
\text { languages and communication } \\
\text { media. }\end{array}$ \\
\hline
\end{tabular}

\section{CONCLUSIONS}

The conclusion of this study is the selection of Islamic prophetic approached in the development of the assessment instrument of teacher's personality competence. This is because the prophet is a human figure chosen by God, who has the goodness of both physical and psychic able to carry out the task from God on earth. The identification of 9 (nine) indicators of prophetic-based personality of a teacher is only limited to the initial step in the preparation of the teacher's competency assessment instrument. These nine indicators will greatly assist the next researcher in preparing the items of the research instrument which is outlined in questionnaires, observation sheets, questionnaires for interviews, or other research instruments. Further studies are required to produce a perfect assessment instrument, as well as to test the validity and reliability of the instrument.

\section{REFERENCES}

[1] Mulyasa, M., "Standar Kompetensi Sertifikasi Guru”, PT Remaja Rosdakarya, 2007.

[2] Mouly, G.J., "Psychology for Effective Teaching," Holt, Rinehart and Winston, 1973.

[3] Santrock, Jhon W., "Educational Psychology", Mc Graw Hill, 2011.

[4] Darajat, Zakiyah., "Kepribadian Guru”, Bulan Bintang, 1982.
[5] Garcia, Patricia Lee Stout, "The Impact of Teacher Personality Styles on Academic Excellence of Secondary Students”, Texas A\&M University-Kingsville, 2010.

[6] Kheruniah, A.E., "A Teacher Personality Competence Contribution to a Student Study Motivation and Discipline to Fiqh Lesson." International Journal of Scientific \& Technology Research 2 (2) 108-112 2013.

[7] Tanabe, Yoshitaka, and Setsuko Mori, "Effects of Perceived Teacher Personality on Student Class Evaluations: A Comparison Between Japanese Instructors and Native English-Speaking Instructors", International Journal of English Linguistics 3 (3), 53, 2013.

[8] Roberts, Brent, Joshua J. Jackson, Angela L. Duckworth, and Katherine Von Culin, "Personality Measurement and Assessment in Large Panel Surveys", In Forum for Health Economics \& Policy, 13(3), 2011.

[9] Shehu, F., "Methodology of Prophetic Da'wah and its Relevance to Contemporary Global Society," Proceeding3rd Kuala Lumpur International Islamic Studies and Civilisations. 26, 2017.

[10] Arifin, S., "Dimensi Profetisme Pengembangan Ilmu Sosial dalam Islam Perspektif Kuntowijoyo," Teosofi: Jurnal Tasawuf dan Pemikiran Islam, 4(2), 477-507, 2014.

[11] Geraudy, Roger, “Janji-Janji Islam,” Bulan Bintang, 1984.

[12] Putra, H.S.A., "Paradigma Profetik Islam", Gajah Mada University Press, 2017

[13] Roqib, M., "Prophetic education; Kontekstualisasi filsafat dan budaya profetik dalam pendidikan." Yogyakarta: Buku Litera, 2011.

[14] Cohen, Ronald Jay, Mark E. Swerdlik, and Suzanne M. Phillips. "Psychological testing and assessment: An introduction to tests and measurement," Mayfield Publishing Co, 1996.

[15] Bradley, J. H., \& Hebert, F. J., "The effect of personality type on team performance," Journal of Management Development, 16(5), 337-353, 1997.

[16] Spencer, L.M., Spencer, S.M., “Competence at Work”, Jhon Wiley \& Sons, Inc, 1993.

[17] Atkinson, Greg, and Alan M. Nevill. "Statistical Methods for Assessing Measurement Error (Reliability) in Variables Relevant to Sports Medicine", Sports medicine 26 (4), 217238, 1998.

[18] Bradley, J. H., \& Hebert, F. J., "The effect of personality type on team performance," Journal of Management Development, 16(5), 337-353, 1997

[19] John, O. P., \& Srivastava, S., "The Big-Five trait taxonomy: History, measurement, and theoretical perspectives. In L. A. Pervin \& O. P. John (Eds.), Handbook of personality: Theory and research", Vol. 2, pp. 102-138, New York: Guilford Press, 1999. 